\title{
Dental Indications of Polynesian Affinity for Prehistoric Rotuma Islanders, South Pacific
}

\author{
Christy G. Turner II* \\ Department of Anthropology, Arizona State University, Tempe
}

\begin{abstract}
Human skeletal reburial, reasonable from a religious and personal point of view, nevertheless diminishes the physical record of human evolution. The present study preserves some information for a small but rare Pacific Basin skeletal assemblage. Prehistoric human tooth-bearing cranial and jaw fragments and loose teeth of probably 19 individuals excavated on Rotuma Island were examined for crown and root morphology. The purpose of the examination was to assess whether these individuals were morphologically more like Melanesians or Polynesians. Rotuma is in the Polynesian culture area north of the Fiji group, which
\end{abstract}

This note is based on observations made on a small sample of prehistoric human teeth from excavations on Rotuma Island submitted to the author for analysis by Richard Shutler, Jr. He and Jamie Evrard directed test excavations in June and July, 1981, one resulting in the recovery of human remains from ROT 2-9, an archaeological site in the Oinafa District location called Risumu on the east end of Rotuma Island. Rotuma is remotely located in the mid-Pacific. Volcanic in origin and only $25 \mathrm{~km}^{2}$ in area, it is in the western Polynesian Outlier culture division of Oceania at approximately $12^{\circ} 25^{\prime} \mathrm{S}$ and $177^{\circ} 5^{\prime} \mathrm{E}$. The Risumu site is the legendary landing place of the first immigrants, supposedly from Tonga, who are said to have arrived about one thousand years ago (Shutler and Evrard, 1991:136). The people of Tonga are Polynesians, and the present-day Rotuma islanders speak a language that is classified as Polynesian, although its exact genetic relationship to other Polynesian languages is unclear (Shutler, 1998: 252). Melanesian populations occupy the Solomon Islands to the west and Fiji to the south, whereas Polynesians are settled on Samoa to the east. The human remains were found in a burial mound (Rot 2-9, test 4, level 4) at a depth of $90-100 \mathrm{~cm}$. There were no cultural remains associated with the human teeth and bones. This small but geographically rare assemblage has since been reburied after study. However, before reburial Shutler had a sample of the human bone dated in the carbon 14 laboratory on his campus at Simon Fraser University, Burnaby, British Columba, Canada. The assay (SFU-118) produced an uncorrected date of 1,000 $\mathrm{BP} \pm 100$ radiocarbon years (Shutler, 1998). exhibits archaeological and ethnographic evidence of colonists from both Oceanic populations. Polynesians belong to the Malayo-Polynesian language family, so if the Rotuma teeth are similar to Polynesians they should also be more similar to Southeast Asian teeth than to those of linguistically different Melanesians or Australians. Indeed, this seems to be the case, although the small Rotuma sample size reduces confidence somewhat in this finding of Rotuma similarity with Polynesians and Southeast Asians. Dental Anthropology 2005;18(2):54-60.

\section{MATERIALS AND METHODS}

The number of Rotuma individuals based on maxillary teeth is 14; mandibular teeth, 17; maxillary and mandibular, 18; probable total, 19. Following standardized observation and scoring procedures for non-metric dental traits (Turner et al., 1991), crown and root morphology was analyzed by univariate and multivariate statistics to estimate Rotuma's phenetic dental relationships with selected comparative populations. The regions chosen for comparison were (1) South Pacific, because of geographic proximity; (2) Southeast Asia, because of ultimate linguistic homeland; and (3) Native America because of T. Heyerdahl's (1952) hypothesis that Polynesians originated from the Americas. Although large samples are always desired in assessing affinity for archaeologically-derived and usually incomplete and fragmentary skeletal samples, it appears that the Rotuma series is adequate for moderately confident inferences about probable past inter-group relationships. The ten comparative dental series used to identify Rotuma relationships are part of the published and unpublished data base in the author's computer and other files. The traits selected for comparison are those that occur most frequently in the Rotuma series. Incisor shoveling, for example, was used because some teeth are present with, and have limited wear of, the trait that permits confident scoring,

${ }^{*}$ Correspondence to: Christy G. Turner II, Department of Anthropology, Arizona State University, Tempe, AZ 85287-2402

E-mail: christyturner@aol.com 


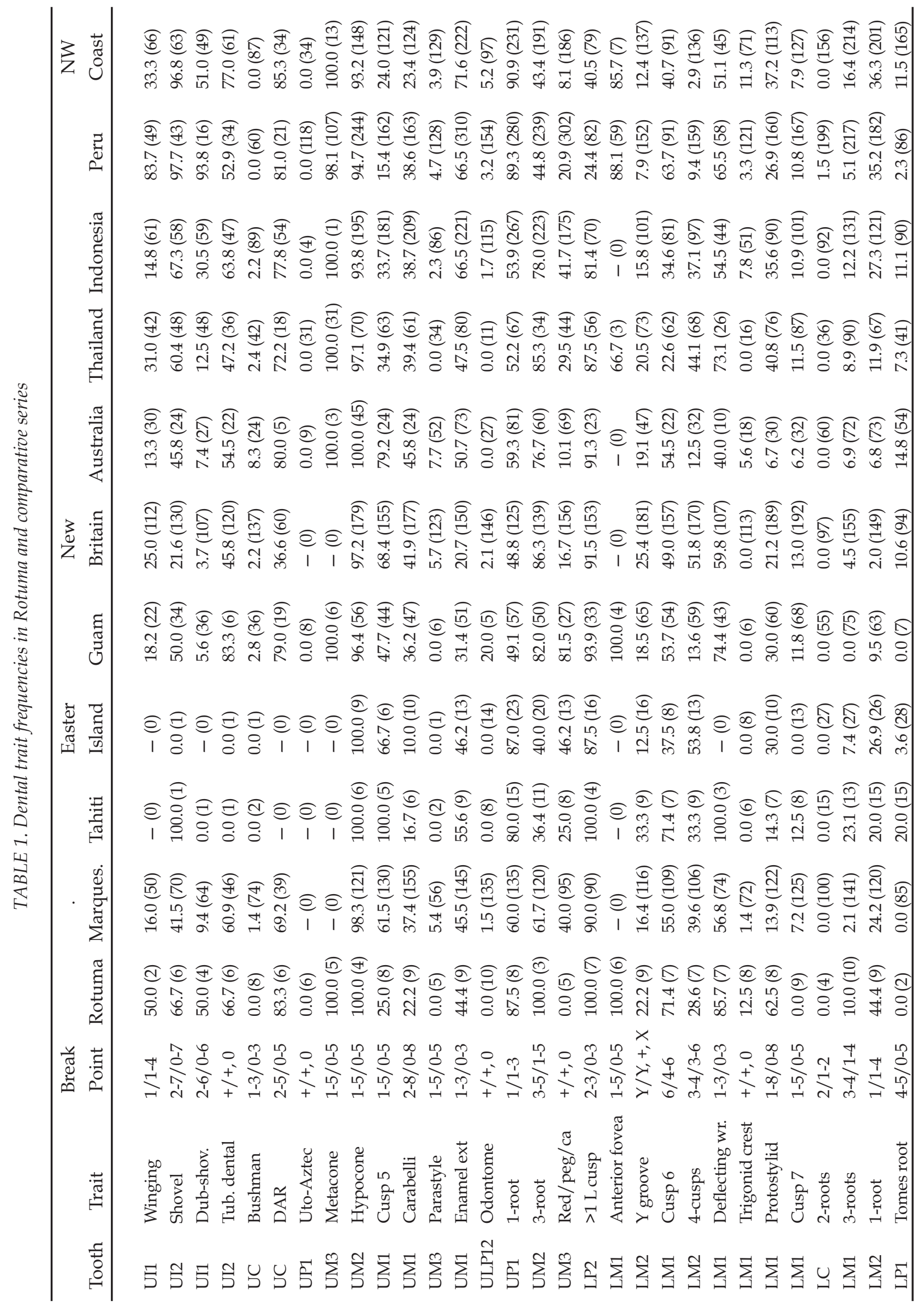


whereas other traits are either absent (missing data) or their amount of occlusal wear exceeds the maximum for confident scoring (see various comments about wear in Turner et al., 1991). Most of these crown traits, but not the root traits, have been previously subjected to hereditary study and are believed to have a strong genetic component in their occurrence and expression (Scott, 1973; Harris, 1977; Nichol, 1990). Table 1 shows the various trait frequencies for Rotuma and the comparative assemblages. Counts are by individuals, sexes are pooled, and dichotomizing frequency break points are identified in Table 1, which are necessary for the computation of both chi-square and the multivariate Mean Measure of Divergence statistic (Berry and Berry, 1967; Sjøvold, 1973). This multivariate statistic is preferred over others because of its relative simplicity and because it readily handles the problem of missing data.

\section{RESULTS}

Univariate comparisons using chi-square $(1 \mathrm{df}$, Yates corrected when any expected cell is less than 5, P significant at 0.05 , all observed cells had to be greater than 0) between Rotuma and the ten comparative Oceanic and circum-Pacific samples in Table 1 gave the following percentages of significant trait frequency differences: Rotuma and Easter, $0.0 \%$ ( 0 out of 23 possible comparisons); Indonesia, 0.0\% (0/29); Marquesas, 3.7\% (1/27); Tahiti, 4.0\% (1/25); Thailand, 6.7\% (2/30); Guam, $6.7 \%$ (2/30); Peru, 6.7\% (2/30); Northwest Coast of Alaska and western Canada, 10.0\% (3/30); Australia, $10.3 \%$ (3/29); New Britain, $14.8 \%$ (4/27). In terms of culture area and linguistic family classifications, Easter, Marquesas, and Tahiti are Polynesian; Indonesia and Thailand are Southeast Asian; Guam is Micronesian; Australia and New Britain are Australmelanesian; and Northwest Coast and Peru (the two areas that Hyerdahl suggested Polynesians might have come from) are Native American-Amerind.

The Rotuma dental traits that showed significant inter-group frequency differences were: Shoveling (Rotuma vs. New Britain, 2 = 4.3; Peru, 4.5; Northwest Coast, 4.7); double-shoveling (New Britain, 8.6); upper molar cusp 5 (Tahiti, 4.3; New Britain, 5.3; Australia, 6.7); peg-reduced-congenitally absent upper third molars (Guam, 10.1); >1 lingual cusp of lower second premolar (Northwest Coast, 7.1; Peru, 14.3); lower molar cusp 6 (Thailand, 6.0); 4-cusped lower second molar (Northwest Coast, 5.9); protostylid (New Britain, 5.8; Marquesas, 9.4; Australia, 10.9); 1-rooted lower second molar (Thailand, 4.7; Guam, 6.0; Australia, 8.8; New Britain, 27.7). Several nearly significant frequency differences possibly would have been significant had the Rotuma series been larger, and these differences likely would have enhanced the differences between Rotuma and the Australmelanesian and American dental series.
Since five percent significant differences can be expected on the basis of chance alone, these univariate comparisons suggest that this Rotuma dental sample is statistically indistinguishable from those originating in the Marquesas, Tahiti, Easter, and Indonesia locations (which includes teeth from younger levels at Niah Cave, Malay near Singapore, other Malays, Philippines, Bangkok, and the Atayal of Taiwan), and only barely distinguishable from teeth from Guam, Thailand (archaeological Don Klang, Ban Tong, Non Nok Tha, and Ban Chiang pooled), and Peru. The Rotuma dental sample is easily distinguished from those originating in New Britain, north and south Australia, and Northwest Coast of North America.

Univariate comparisons show Rotuma to be indistinguishable from the known Polynesian samples. Compared with Australmelanesians, Rotuma and the Polynesians possess relatively high frequencies of incisor shoveling, deflecting wrinkle, protostylid, 3-rooted lower first molar, and 1-rooted lower second molars. They have low frequencies of the pronounced mesial-ridged upper canine (Bushman canine), Carabelli's cusp, and the parastyle. These frequencies are characteristic of the Southeast Asian dental pattern I have called Sundadonty in contrast to the Northeast Asian and New World pattern termed Sinodonty (Turner, 1979, and elsewhere).

Multivariate comparisons were made using 23 to 30 traits available in the comparative samples (Table 2). Because the Rotuma series is small, few of the computed Mean Measures of Divergence (MMD) are significant. This coupled with the fact that the number of traits compared differed slightly between comparative pairs, indicates that more reliability should be placed on the univariate findings and inferences. Definitely, no strictly "literal" interpretation should be made of the MMD values, however, relatively, they generally follow what was inferred from the univariate comparisons. Given that the number of trait pairs was not identical in all inter-group comparisons, I perhaps should have attempted to "standardize" the MMD values. It is a happy coincidence that I did not, because following the submission of this article to Dental Anthropology, I have read the important article by Harris and Sjøvold (2004) that, among other MMD considerations, convincingly demonstrates the inappropriateness of MMD standardization.

As with the univariate comparisons, the MMD values of Table 2 show that Rotuma is more like most Polynesians than like New Britain. Australia occupies an intermediate position, both in relation to Rotuma $(\mathrm{MMD}=0.061)$ and New Britain $(\mathrm{MMD}=0.057)$. Rotuma has no measurable MMD dissimilarity to Tahiti, Thailand and Indonesia, and effectively no divergence from Easter. This odontological association of Rotuma with Polynesians and Southeast Asians is 
TABLE 2. Mean Measures of Divergence for Rotuma and comparative dental samples ${ }^{1}$

\begin{tabular}{llllllllllll}
\hline & ROT & TAHI & THAI & INDO & EAST & NWC & AUST & GUAM & MARQ & PERU & NEW B \\
\hline ROT & & 25 & 30 & 29 & 23 & 30 & 29 & 30 & 27 & 30 & 27 \\
TAHI & 0.000 & & 25 & 25 & 23 & 25 & 25 & 25 & 25 & 25 & 25 \\
THAI & 0.000 & 0.041 & & 29 & 23 & 30 & 29 & 30 & 27 & 30 & 27 \\
INDO & 0.000 & 0.071 & 0.000 & & 23 & 29 & 29 & 29 & 27 & 29 & 27 \\
EAST & 0.007 & 0.000 & 0.015 & 0.045 & & 23 & 23 & 23 & 23 & 23 & 23 \\
NWC & 0.057 & 0.223 & 0.223 & 0.135 & 0.303 & & 29 & 30 & 27 & 30 & 27 \\
AUST & 0.061 & 0.000 & 0.067 & 0.050 & 0.033 & 0.262 & & 29 & 27 & 29 & 27 \\
GUAM & 0.074 & 0.130 & 0.065 & 0.050 & 0.100 & 0.313 & 0.097 & & 27 & 30 & 27 \\
MARQ & 0.090 & 0.021 & 0.058 & 0.073 & 0.000 & 0.324 & 0.039 & 0.060 & & 27 & 27 \\
PERU & 0.138 & 0.307 & 0.347 & 0.275 & 0.270 & 0.093 & 0.452 & 0.450 & 0.452 & & 27 \\
NEW B & 0.160 & 0.087 & 0.074 & 0.182 & 0.028 & 0.528 & 0.057 & 0.152 & 0.075 & 0.665 & \\
\hline
\end{tabular}

${ }^{1}$ Whole numbers are the number of pairs of traits used to calculate the inter-group MMD values. Thus, there were 25 traits involved in the MMD comparison between Rotuma and Tahiti, and 30 used for the Rotuma-Thailand MMD. MMD values are shown as fractions with small values representing greater similarity than larger values. Thus, Rotuma is more similar to Easter (0.007) than it is with New Britian (0.160). MMD values were calculated according to C.A.B. Smith (Berry and Berry, 1967) with the modifications suggested by Sjøvold (1973) and Green and Suchey (1976).

quite suggestive of proximate (when the Rotuma people were alive) and close ties with known Polynesians, and close ultimate links with Southeast Asian Sundadonts. Insofar as sample size permits, Rotuma cannot be multivariately distinguished from Polynesians, whereas it can be when compared with Melanesians. Since Polynesian and Melanesian populations are the most realistic geographic sources for this Rotuma sample, the former are a better bet than the latter for having been close relatives. The Micronesian people of Guam belong to the Sundadont dental class, so it is not unexpected that inter-group similarities and differences parallel those of Rotuma. Given the very great oceanic distance separating Guam and Rotuma, their relative similarity is best attributed to their shared ultimate Sundadont ancestry in Southeast Asia. A similar inference was made earlier by Harris et al. (1975:231) regarding the stronger dental relationships between the Yaps of Micronesia and Polynesians, in contrast to the much weaker relationship between Yaps and Australmelanesians. In large-scale comparisons, both Pietrusewsky (1990), using craniometric observations, and the author (Turner, 1990) using dental morphology, found Guam skulls and teeth to be much more like those of Southeast Asians and Polynesians than like various Australian, Melanesian, and Tasmanian samples. However, when Turner pooled Rotuma and Fiji dental samples, because of their relative Oceanic closeness, this combined group was most like samples from Early Malay Archipelago, and from Melanesian-Polynesian border islands. Fiji has a history of both Polynesian and Melanesian occupation. The Fiji dental sample was considered to be Polynesian, but it would appear this was incorrect because the Fiji-Rotuma combination clustered with Australmelanesians instead of Sundadont Southeast Asians, Polynesians, and Guam Micronesians. Yet, the study by Weets (1996) on the dentition of Vanuatu islanders, near Fiji, in eastern Melanesia, found that these people were more like Polynesians and east Asians than like Melanesians. Hence, large-scale boundaries in Oceania defined culturally and linguistically generally have high correspondence with dentally-defined communities. Rotuma alone classifies as Polynesian, but when combined with nearby Fiji its affiliation becomes ambiguous.

\section{DISCUSSION}

Both univariate and multivariate statistical comparisons of the small Rotuma dental sample indicate a closer relationship with Polynesians than with Melanesians or American Indians. In addition, the Rotuma teeth are very similar to those of Southeast Asians. Since numerous other assessments of affinity based on these same dental traits have produced expected results when evaluated with independent archaeological, linguistic, or ethnographic information (Scott and Turner, 1997), there is good reason to hypothesize a strong Rotuma-Polynesian linkage, depending, of course, on how one feels about the size of the Rotuma sample. Although no cultural remains were found with the Rotuma bones and teeth, Shutler and Evrard (1991) argued that the Rotuma oral traditions strongly indicated a Polynesian cultural affiliation.

Differences between human groups are due to evolutionary processes, with genetic drift or founder's effect figuring prominently in small groups, especially 
for traits of little or no identifiable adaptive value, such as enamel extensions or occlusal surface characters that wear off early in life. Such traits, especially if their mode of inheritance is relatively simple, should show increased inter-group frequency differences, with increased amounts of temporal separation. For example, the MMD between American Indians and Northeast Asians is 0.154 (Turner, 1986). Most archaeological evidence suggests that these two geographic groups have been physically separated on the order of 12,000 to 15,000 years (Fiedel, 2004; several others). The averaged MMD between Rotuma and the Polynesians, compared with Thailand-Indonesians is 0.038 , about four times less that the Indian-Northeast Asian MMD value. As time and MMD values between separated groups has been suggested as roughly proportional (Turner 1986), then an MMD separation estimate between Polynesians and Southeast Asians would be about 3,000 years. Such an estimate corresponds fairly well with radiocarbon dates of about 1,000 B.C. from early Tonga (Shutler and Shutler, 1975; Bellwood, 1979) and several other excavated Polynesian sites (Green, 1994).

Pooling the same Rotuma and Polynesian samples and comparing their MMD values with New Britain gives an averaged MMD of 0.087 . This is two to three times greater that the Rotuma-Polynesian/Southeast Asian comparison and produces an estimated 8,000 to 9,000 years of separation. Such a date vastly exceeds any dated archaeological site in Polynesia. So, it would seem that archaeological chronometrics when linked to mega-regional dental MMD values, also leans towards a Polynesian identification of this Rotuma dental sample. Finally, nothing more needs to be said regarding a New World origin for Polynesians, other than there is no dental evidence in support of this hypothesis. This is as true today as it was more than 25 years ago when the author and G. Richard Scott (1977) set out to describe and assess the affinity of living Easter Islanders based on dental morphology. Then, as now, Easter and all other Polynesian dental evidence points to Southeast Asia as the Polynesian homeland, not the Americas nor Melanesia.

Finally, a word or two needs to be said about the population history of the ultimate ancestral homeland of the Rotuma and other Polynesian islanders. This ancestral homeland is usually considered to be in Southeast Asia, which is referred to as Sundaland when in ice age Pleistocene times sea levels were lower and all of island and mainland Southeast Asia were connected by dry land. The prehistoric and recent teeth of the people of Sundaland possess the dental pattern previously referred to as Sundadonty. Recently, Matsumura and Hudson (2005) have challenged the local evolution hypothesis used to explain the origin of Sundadonty, returning instead to the older idea of "southern Mongoloids" being the result of Neolithic migrants from China mixing with Southeast Asian Australmelanesians. There are several reasons why the old migrant-mixture scenario is flawed, not the least of which is that hybridized populations sometimes do not breed true (Turner, n.d.). There can be resulting offspring that exhibit the original characteristics of the parental stocks instead of the hybrid intermediacy condition. None of the samples of Polynesians that I have examined exhibit a dental pattern that could be considered Australmelanesian or Chinese (Sinodonty). Despite the absence of archaeological evidence that the Rotuma dental sample should be considered Polynesian, oral tradition, cemetery location, island location, dating, and dental characteristics strongly suggest that it is Polynesian. Hence, it provides yet another Polynesian isolate that supports the local evolution hypothesis for the origin of Sundadonty.

\section{CONCLUSION}

A small but geographically rare sample of archaeologically-derived teeth from Rotuma Island shares more crown and root morphological resemblances with teeth from Polynesian and Southeast Asian dental samples than it does with teeth from the Melanesian island of New Britain. On the basis of these comparisons, it is concluded that this Rotuma dental sample originated from a population that had a greater epigenetic relationship with Polynesians than with Melanesians. Being relatively near the border zone between Melanesia and Polynesia, Rotuma Island may have had chronologically or geographically both Melanesian and Polynesian occupants; however, the sample discussed herein can easily be hypothesized as having been Polynesian. Dental morphology, linguistic classification, and oral traditions independently favor a Polynesian affiliation for these Rotuma human remains. The Rotuma teeth also help reconfirm the local evolution hypothesis for the origin of Sundadonty.

\section{ACKNOWLEDGMENTS}

Data and earlier analyses on the comparative series was gathered with grants from the National Geographic Society, The Wenner-Gren Foundation for Anthropological Research, and Arizona State University Faculty Grant Program. The following institutions housed the comparative series when studied: American Museum of Natural History, New York; Bishop Museum, Honolulu; National Museum of Natural History, Smithsonian Institution, Washington, D.C.; Burke Museum, University of Washington, Seattle; Archaeological Survey of Canada, Ottawa; University of British Columbia, Vancouver; Peabody Museum, Harvard University, Cambridge; University of Arkansas, Fayetteville; University of Pennsylvania Museum, Philadelphia; University of Nevada, Las Vegas; University of Hawaii, Honolulu, Field Museum 
of Natural History, Chicago; Academia Sinica, Taipei; San Diego Museum of Man, San Diego; Simon Fraser University, Burnaby. Data processing and entry were aided by Linda Nuss (Watson). Richard Shutler kindly made the dental sample available for study. This is contribution number 33 in my Peopling of the Pacific Basin and Adjoining Areas series.

\section{LITERATURE CITED}

Bellwood P. 1979. Man's conquest of the Pacific: the prehistory of Southeast Asia and Oceania. New York: Oxford University Press.

Berry AC, Berry RJ. 1967. Epigenetic variation in the human cranium. J Anatomy 101:361-379.

Fiedel S. 2004. The Kennewick follies. J Anthropol Research 60:75-110.

Green R. 1994. Changes over time: recent advances in dating human colonisation of the Pacific Basin area. In: Sutton DG, editor. The origins of the first New Zealanders. Auckland, p 1-33.

Green R, Suchey J. 1976. The use of the inverse sine transformation in the analysis of non-metrical cranial data. Am J Phys Anthropol 45:61-68.

Harris EF. 1977. Anthropologic and genetic aspects of the dental morphology of Solomon islanders, Melanesia. Ph.D. dissertation, Arizona State University, Tempe.

Harris EF, Turner CG II, Underwood JH. 1975. Dental morphology of living Yap islanders, Micronesia. Archaeol \& Phys Anthropol in Oceania 10:218-234.

Harris EF, Sjøvold T. 2004. Calculation of Smith's Mean Measure of Divergence for intergroup comparisons using nonmetric data. Dental Anthropolology 17: 83-93.

Heyerdahl T. 1952. American Indians in the Pacific. Chicago: Rand McNally.

Howells WW. 1973. The Pacific islanders. New York: C. Scribner's Sons.

Matsumura H, Hudson MJ. 2005. Dental perspectives on the population history of Southeast Asia. Am J Phys Anthropol 127:182-209.

Nichol CR. 1990. Dental genetics and biological relationships of the Pima Indians of Arizona. Ph.D. dissertation, Arizona State University, Tempe.

Pietrusewsky M. 1990. Craniometric variation in Micronesia and the Pacific: a multivariate study. In: Hunter-Anderson RL, editor. Recent advances in Micronesian archaeology. Supplement 2, Micronesica. Mangilao: University of Guam Press, p 373-402.

Scott GR. 1973. Dental morphology: a genetic study of American White families and variation in living Southwest Indians. Ph.D. dissertation, Arizona State University, Tempe.
Scott GR and Turner CG II. 1997. The anthropology of modern human teeth: dental morphology and its variation in recent human populations. Cambridge: University of Cambridge Press.

Shutler R Jr. 1998. Rotuma in historic and prehistoric perspective. Asian Profile 26:251-254.

Shutler R Jr., Evrard JS. 1991. Rotuma: a case of archaeology documenting the Rotuman oral tradition of the first Tongan landing. Man and Culture in Oceania 7:133-137.

Shutler R Jr., Shutler ME. 1975. Oceanic prehistory. Menlo Park: Cummings Publishing Company.

Sjøvold T. 1977. Non-metrical divergence between skeletal populations. Ossa 4:1-133.

Turner CG II. 1979. Sinodonty and Sundadonty: a dental anthropological view of Mongoloid microevolution, origin, and dispersal into the Pacific basin, Siberia, and the Americas. In: Vasilievsky RS, editor. Late Pleistocene and early Holocene cultural connections of Asia and America. Novosibirsk: USSR Acad Sci, Siberian Branch, p.762-76 [Russian].

Turner CG II. 1986. Dentochronoloigcal separation estimates for Pacific rim populations. Science 232: 1140-1142.

Turner CG II. 1990. Origin and affinity of the people of Guam: a dental anthropological assessment. In: Hunter-Anderson RL, editor. Recent advances in Micronesian archaeology. Supplement 2, Micronesica. Mangilao: University of Guam Press, p 403-416.

Turner CG II. n.d. Dental morphology and the population history of the Pacific Rim and Basin: commentary on Hirofumi Matsumura and Mark J. Hudson. Am J Phys Anthropol [Under Review.]

Turner CG II, Scott GR. 1977. Dentition of Easter islanders. In: Dahlberg AA, Graber TM, editors. Orofacial growth and development. The Hague: Mouton Publishers, p 229-249.

Turner CG II, Nichol CR, Scott GR. 1991. Scoring procedures for key morphological traits of the permanent dentition: the Arizona State University dental anthropology system. In: Kelley MA, Larsen CS, editors. Advances in dental anthropology. New York: Wiley-Liss, p 13-31.

Weets JD. 1996. The dental anthropology of Vanuatu, eastern Melanesia. M.A. thesis, Anthropology, Arizona State University, Tempe. 